\title{
ИЗУЧЕНИЕ АНТИАГРЕГАНТНОГО ДЕЙСТВИЯ НОВОГО КЛАССА ПРОИЗВОДНЫХ БЕНЗИМИДАЗОЛА, ИМЕЮЩИХ В СВОЕЙ СТРУКТУРЕ ПРОСТРАНСТВЕННО ЗАТРУДНЕННЫЙ ФЕНОЛЬНЫЙ ЗАМЕСТИТЕЛЬ
}

\author{
А.А. Спасов', А.Ф. Кучерявенко', К.А. Гайдукова', О.Н. Жуковская² \\ ${ }^{1}$ Волгоградский Государственный Медицинский Университет Минздрава РФ, 400131, \\ Россия, г. Волгоград, пл. Павших Борцов, 1. \\ ${ }^{2}$ Научно-исследовательский институт физической и органической химии \\ ФГАОУ ВО «Южный федеральный университет»; \\ Россия, 344090 Ростов-на-Дону, пр. Стачки, 194/2.
}

DOI: 10.19163/MedChemRussia2021-2021-478

E-mail:ksenijagajjdukva@rambler.ru

Современная антиагрегантная терапия проводится с использованием фармакологических средств, которые, несмотря на их высокую эффективность, обладают рядом побочных явлений, что служит серьезным ограничением при их применении. В ранее проведенных исследованиях была выявлена способность некторых производных бензимидазола блокировать процессы агрегации тромбоцитов, а также наличие антиоксидантной активности у представителей данного класса, в молекулярном остове которых присутствуют «ловушки» свободных радикалов. Именно поэтому поиск новых соединений с антиагрегантной активностью в ряду производных бензимидазола, имеющих в структуре экранированный фенольный заместитель, является весьма актуальным.

После выявления среди данных производных наиболее активных веществ, синтезированных в НИИ Физической и органической химии Южного Федерального университета, было найдено соединение-лидер под шифром РУ-1144, проявляющее выраженное сочетанное антитромбогенное и антиоксидантное действие [1].

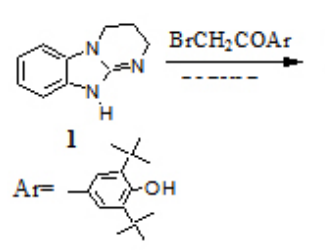<smiles>CCOC(=O)C1=NCCCN1c1ccccc1Br</smiles>

2

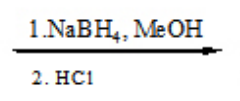

$$
\text { Py-1144 }
$$<smiles>OC(Cl)CN1C2=NCCCN2c2ccccc21</smiles>

$\mathrm{CH}_{2} \mathrm{CH}(\mathrm{OH}) \mathrm{Ar}$

Соединение 2 получали прямым введением в трицикл 1 ацилметильной группы с помощью 3,5-ди-трет-бутил-4-гидроксифенацил бромида. При восстановлении кетона 2 борогидридом натрия в метаноле получали спирт, РУ-1144. Исходный 2,3,4,10-тетрагидро пиримидо[1,2-a]бензимидазол(1) образуется при термической внутримолекулярной циклизации 3-(3-хлорпропиламино)бензимидазола. Последний получали действием тионил хлорида на 3-(3-гидроксипропиламино)бензимидазол, синтезированный нагреванием 3-пропаноламина с бензимидазол-2-сульфокислотой.

\section{Литература}

[1] A.A.Spasov, A.F.Kucheryavenko,K.A. Gaidukova,V.A. Kosolapov, O.N.Zhukovskaya Antiplatelet activity of new derivatives of benzimidazole containing sterically hindered phenolic group in their structure. Research Results in Pharmacology.2020, T. 6, № 1, C. 1-9. 